\title{
The influence of thermal processing of sewage sludge on the usage properties of the formed ash
}

\author{
Katarzyna Gorazda, Zbigniew Wzorek, Marek Jodko \\ Cracow University of Technology, Institute of Chemistry and Inorganic Technology, ul. Warszawska 24, 31-155 Kraków, \\ Poland, e-mail: gorazda@chemia.pk.edu.pl
}

\begin{abstract}
The influence of sewage sludge incineration temperature on the formed ash constitution was examined. The comparative extraction tests of two differently prepared ashes (laboratory and industrial) were carried out in order to verify if the parameters of sewage sludge incineration influence the extraction selectivity of phosphorus compounds. The laboratory ash $\left(A_{l a b}\right)$ were prepared from sewage sludge incinerated at $950^{\circ} \mathrm{C}$ on a laboratory scale while the industrial ash $\left(A_{\text {ind }}\right)$ comes from thermal utilization system of the sewage sludge at the Gdynia Sewage Treatment Plant, which uses fluid-bed furnace incineration at $850-900^{\circ} \mathrm{C}$. It was found that the temperature and the conditions of the sewage sludge incineration process have an effect on the usage properties of the formed ash. Despite the twofold lower Fe content in the industrial ash than that of the laboratory one, its content in extracts after phosphoric acid leaching is 4.7 times higher. The lower values of $\mathrm{PO}_{4}^{3-}$ leaching degree from the industrial ash than the laboratory ash were observed, as well as a decrease of extraction productivity.
\end{abstract}

Keywords: phosphorus recovery, ash properties, ash extraction, industrial ash.

Presented at VII Conference Wasteless Technologies and Waste Management in Chemical Industry and Agriculture, Międzyzdroje, 12 - 15 June, 2007.

\section{INTRODUCTION}

The sewage sludge, waste after municipal sewage treatment processes, are the source of mineral and organic elements including a series of valuable fertilizing components, which make them a potential substitute for natural phosphorus ore.

The sewage sludge causes significant problems in the global system of waste management because of its complicated composition and properties, ${ }^{\mathbf{1}, 2}$. Currently the prevailing method of management in Poland, is storage. The thermal utilization methods are applied only for $2 \%$ of generated sewage sludge but the importance systematically increases because they allow a significant mass reduction, concentration of the inorganic fraction as ash and remove the bacteriological menace thoroughly ${ }^{3}$.

The driving force for the development of thermal utilization methods are high storage costs of sewage sludge as well as the plans for the modification of EU Directive 86/ 278 in the direction of a more restrictive approach to its agricultural utilization ${ }^{4-6}$.

Presently there are several systems for phosphorus recovery from sewage sludge - Cambi/KreproTM and BioCon created in the Netherlands, but only a few that propose ash treatment ${ }^{7-9}$. EBRP - the Japanese process should be mentioned here as it proposes intensive ash washing with demineralized water at $53^{\circ} \mathrm{C}^{8}$. A further solution, investigated on a laboratory scale, is phosphorus extraction from ash with the use of sulfuric acid'. The phosphate was precipitated from the solution by the addition of aluminum sulfate and sodium bicarbonate addition $(\mathrm{pH} \sim 4)$. The acquired product might be used as a binding or refractory material and a raw material for glass production. Nevertheless, the authors claim that so far there has been no industrial technology in which such a product could be used. Japan Sewage Works and Sanki Engineering Co. Ltd. ${ }^{10,11}$ developed a fertilizer produc- tion technology, melted calcium-magnesium phosphate, on the basis of ash from sewage sludge combustion. This method consists in ash melting with an addition of calcium and magnesium at the temperature of $1350-1500^{\circ} \mathrm{C}$. Then the alloy is water-cooled and steered to fertilizer production, which fulfills the requirements of Japanese fertilizers standards. In the year 2000 the Japanese technology of phosphorus recovery from ash or sewage sludge in the form of white phosphorus or phosphoric acid was patented ${ }^{12}$.

Our earlier investigations, to the influence of sewage sludge combustion temperature on the obtained ash composition, reveal that ash extraction selectivity depends significantly on the parameters of its thermal processing ${ }^{13-15}$. In the instance when the sewage treatment plant uses chemical precipitation for phosphorus removal in the form of iron phosphate, the sewage sludge, as well as the obtained ash, contain unwanted iron ions, which have an unfavorable impact on phosphorus availability in fertilizers or feed products.

The conducted investigations allowed a selection of the best parameters of phosphorus compounds extraction from ash (prepared at $950^{\circ} \mathrm{C}$ ) with nitric and phosphoric acid ${ }^{16}$. In the case of nitric acid, application of $0.45[\mathrm{~g} / \mathrm{g}]$ acid to ash mass ratio and acid concentration $2.71\left[\mathrm{~mol} / \mathrm{dm}^{3}\right]$ resulted in $94.89 \%$ of $\mathrm{PO}_{4}{ }^{3-}$ ions recovery and high extraction productivity $-0.423\left[\mathrm{~mol} \mathrm{PO}_{4}^{3-} / \mathrm{mol} \mathrm{HNO}_{3}\right]$. The most favorable conditions for ash extraction with phosphoric acid were: acid to ash mass ratio $-0.45[\mathrm{~g} / \mathrm{g}]$ and acid concentration $-2.68\left[\mathrm{~mol} / \mathrm{dm}^{3}\right]$. The leaching degree of phosphate ions reached was $96,1 \%$ and extraction productivity $-0.35\left[\mathrm{~mol} \mathrm{PO}{ }_{4}^{3-} / \mathrm{mol} \mathrm{HNO}_{3}\right]$.

In order to confirm the influence of sewage sludge combustion conditions on phosphorus extraction selectivity further research was conducted. The main goal was the comparison of extraction results of ashes obtained 
after sewage sludge combustion on a laboratory scale and from the industrial sewage sludge combustion plant.

\section{EXPERIMENTAL SECTION}

The industrial ash $A_{\text {ind }}$ comes from the sewage sludge thermal utilization plant at Municipal Sewage Treatment Plant in Gdynia. The installation with a capacity near 80 $\mathrm{Mg} /$ day combusts sewage sludge with the $70 \%$ moisture $^{17}$. The combustion process is carried out in a fluid-bed furnace at the temperature of $850-900^{\circ} \mathrm{C}$, where sand with $0.2-1.5 \mathrm{~mm}$ grain-size is used as a fluid bed. The sand grains, as a result of movement and polymorphous transformation, undergo a size reduction, then, as a solid phase, are separated from combustion gasses at cyclone and with other incombustible components formed ash. Yearly $2000 \mathrm{Mg}$ of ash is formed from $\sim 20000 \mathrm{Mg}$ of sewage sludge, which is then stored in a dry state at a separate stockyard.

The laboratory ash $A_{l a b}$ was acquired from sewage sludge combustion at $950^{\circ} \mathrm{C}$ for $3 \mathrm{~h}$. The sewage sludge was taken out from the Municipal Sewage Treatment Plant „Kujawy” in Kraków-Pleszów, which uses a three-stages cleaning technology with the activated sludge and the chemical precipitation of phosphorus with iron sulfate. The sewage sludge after methane fermentation and gravity thickening is stored in the quantities of $55 \mathrm{Mg} /$ day.

Table 1. The chemical constitution and the physical parameters of the laboratory ash $A_{l a b}$ and the industrial ash $A_{\text {ind }}$

\begin{tabular}{|l|c|c|}
\hline \multirow{2}{*}{ COMPONENT } & \multicolumn{2}{|c|}{ ASHES } \\
\cline { 2 - 3 } & $A_{\text {lab }}$ & $A_{\text {ind }}$ \\
\hline $\mathrm{PO}_{4}{ }^{3-}[\%]$ & 22.86 & 33.7 \\
\hline $\mathrm{Fe}[\%]$ & 16.63 & 8.95 \\
\hline $\mathrm{Ca}[\%]$ & 11.26 & 11.97 \\
\hline $\mathrm{Mg}[\%]$ & 1.120 & 3.40 \\
\hline $\mathrm{Zn}[\%]$ & 0.54 & 1.136 \\
\hline $\mathrm{Pb}[\%]$ & 0.012 & 0.0137 \\
\hline $\mathrm{Cu}[\%]$ & 0.054 & 0.0709 \\
\hline $\mathrm{Ni}[\%]$ & 0.017 & 0.0113 \\
\hline $\mathrm{Cr}[\%]$ & 0.070 & 0.0844 \\
\hline $\mathrm{Cd}[\%]$ & 0.0020 & 0.00398 \\
\hline $\mathrm{Co}[\%]$ & 0.00510 & 0.00465 \\
\hline $\mathrm{SiO}_{2}[\%]$ & - & 19.5 \\
\hline
\end{tabular}

The chemical constitution and the physical parameters of the industrial ash from the Municipal Sewage Treatment Plant in Gdynia $\left(A_{\text {ind }}\right)$ and the laboratory ash from the Municipal Sewage Treatment Plant „Kujawy” in Kraków-Pleszów $\left(A_{\text {lab }}\right)$ are presented in Table 1.

The results of Thermal and X-Ray Analysis of both ashes are shown in Figures 1,2.

The X-Ray Analysis reveal that the main phases of laboratory ash were quartz and hematite and that the additional crystalline phases (variety of $\gamma-\mathrm{Fe}_{2} \mathrm{O}_{3}$, maghemite- $\mathrm{C}$ and $\left.\mathrm{Ca}_{9} \mathrm{FeH}\left(\mathrm{PO}_{4}\right)_{7}\right)$ were present in the case of the industrial ash.

The ashes were extracted both with nitric (experiment $1 \mathrm{a}$ and $1 \mathrm{~b}$ ) and phosphoric acid (experiment $2 \mathrm{a}$ and $2 \mathrm{~b}$ ). The extraction was carried out for $29 \mathrm{~h}$ in a tight polypropylene reactor and the conditions of the process are shown in Table 2.

\section{RESULTS AND DISCUSSION}

The most important parameters of the conducted experiments: $\mathrm{PO}_{4}{ }^{3-}$ extraction degree and extraction productivity (counted on phosphoric and nitric acid) are shown in Table 3.

The difference in $\mathrm{PO}_{4}{ }^{3-}$ extraction degree between both ashes prepared under different conditions is clearly marked. The laboratory ash extraction with phosphoric acid results in higher $\mathrm{PO}_{4}{ }^{3-}$ extraction degree by $10 \%$ than the industrial ash extraction, in spite of introducing the same quantities of phosphate ions $(8.0 \mathrm{~g})$ with both ashes. In the case of nitric acid extraction, the $\mathrm{PO}_{4}{ }^{3-}$ extraction degree for the laboratory ash is higher than that of the industrial ash extraction even by $19 \%$.

In order to get better acquainted with the differences between the conducted experiments the concentration of $\mathrm{PO}_{4}{ }^{3-}, \mathrm{Ca}^{2+}, \mathrm{Mg}^{2+}$ and $\mathrm{Fe}^{2+}$ ions in the extracts after ash extraction with phosphoric acid (Figure 3 ) and nitric acid (Figure 4) were compared.

The higher extraction degree of phosphate ions from the laboratory ash results in obtaining the extracts with higher phosphate content, $103.9 \mathrm{~g} / \mathrm{dm}^{3}$, respectively, when nitric acid was used and $91.9 \mathrm{~g} / \mathrm{dm}^{3}$ for the phosphoric acid extraction $\left(347.5 \mathrm{~g} / \mathrm{dm}^{3}\right.$, including phosphate ions introduced with the acid). These concentrations in the extracts after the industrial ash extraction amounts are $93.9 \mathrm{~g} / \mathrm{dm}^{3}$ and $78.8 \mathrm{~g} / \mathrm{dm}^{3}\left(330.7 \mathrm{~g} / \mathrm{dm}^{3}\right)$, respectively.

Table 2. The conditions of the ash extraction process with nitric and phosphoric acid

\begin{tabular}{|c|c|c|c|l|c|}
\hline Experimentno. & Ash amount [g] & $\begin{array}{c}\text { Ash/acid mass } \\
\text { ratio[g/g] }\end{array}$ & PO $_{4}{ }^{3-}$ introduced with ash [g] & Acid & Acid concentration [mol/dm ${ }^{3}$ ] \\
\hline $1 \mathrm{a}$ & $35.00 A_{\text {lab }}$ & 0.447 & 8.00 & Nitric acid & 2.71 \\
\hline 1b & $23.60 A_{\text {ind }}$ & 0.302 & 8.00 & & 2.71 \\
\hline $2 \mathrm{a}$ & $30.00 A_{\text {lab }}$ & 0.370 & 6.86 & Phosphoric acid & 2.68 \\
\hline 2b & $20.23 A_{\text {ind }}$ & 0.250 & 6.86 & & 2.68 \\
\hline
\end{tabular}

Table 3. A compilation of extraction degree and extraction productivity for the experiments of ash extraction with nitric and phosphoric acid

\begin{tabular}{|c|c|c|c|}
\hline Experiment No & $\begin{array}{c}\text { Ash/acid mass ratio } \\
{[\mathrm{g} / \mathrm{g}]}\end{array}$ & $\mathrm{PO}_{4}{ }^{3-}$ extraction degree [\%] & Extraction productivity \\
\hline $\begin{array}{c}\text { Experiment 1a } \\
A_{\text {lab } \text { extraction }}\end{array}$ & 0.447 & 94.85 & $0.423\left[\mathrm{~mol} \mathrm{PO}_{4}{ }^{3-} / \mathrm{mol} \mathrm{HNO}_{3}\right]$ \\
\hline $\begin{array}{c}\text { Experiment 1b } \\
A_{\text {ind }} \text { extraction }\end{array}$ & 0.302 & 86.33 & $0.383\left[\mathrm{~mol} \mathrm{PO}_{4}{ }^{3-} / \mathrm{mol} \mathrm{HNO}_{3}\right]$ \\
\hline $\begin{array}{c}\text { experiment 2a } \\
A_{\text {lab }} \text { extraction }\end{array}$ & 0.370 & 96.10 & $0.355\left[\mathrm{~mol} \mathrm{PO}_{4}{ }^{3-} / \mathrm{mol} \mathrm{H}_{3} \mathrm{PO}_{4}\right]$ \\
\hline $\begin{array}{c}\text { Experiment 2b } \\
A_{\text {ind }} \text { extraction }\end{array}$ & 0.250 & 81.07 & $0.308\left[\mathrm{~mol} \mathrm{PO}_{4}{ }^{3-} / \mathrm{mol} \mathrm{H}_{3} \mathrm{PO}_{4}\right]$ \\
\hline
\end{tabular}


Sample

Size: $20.6569 \mathrm{mg}$

TGA-DTA

Comment: 10-1100 Powietrze

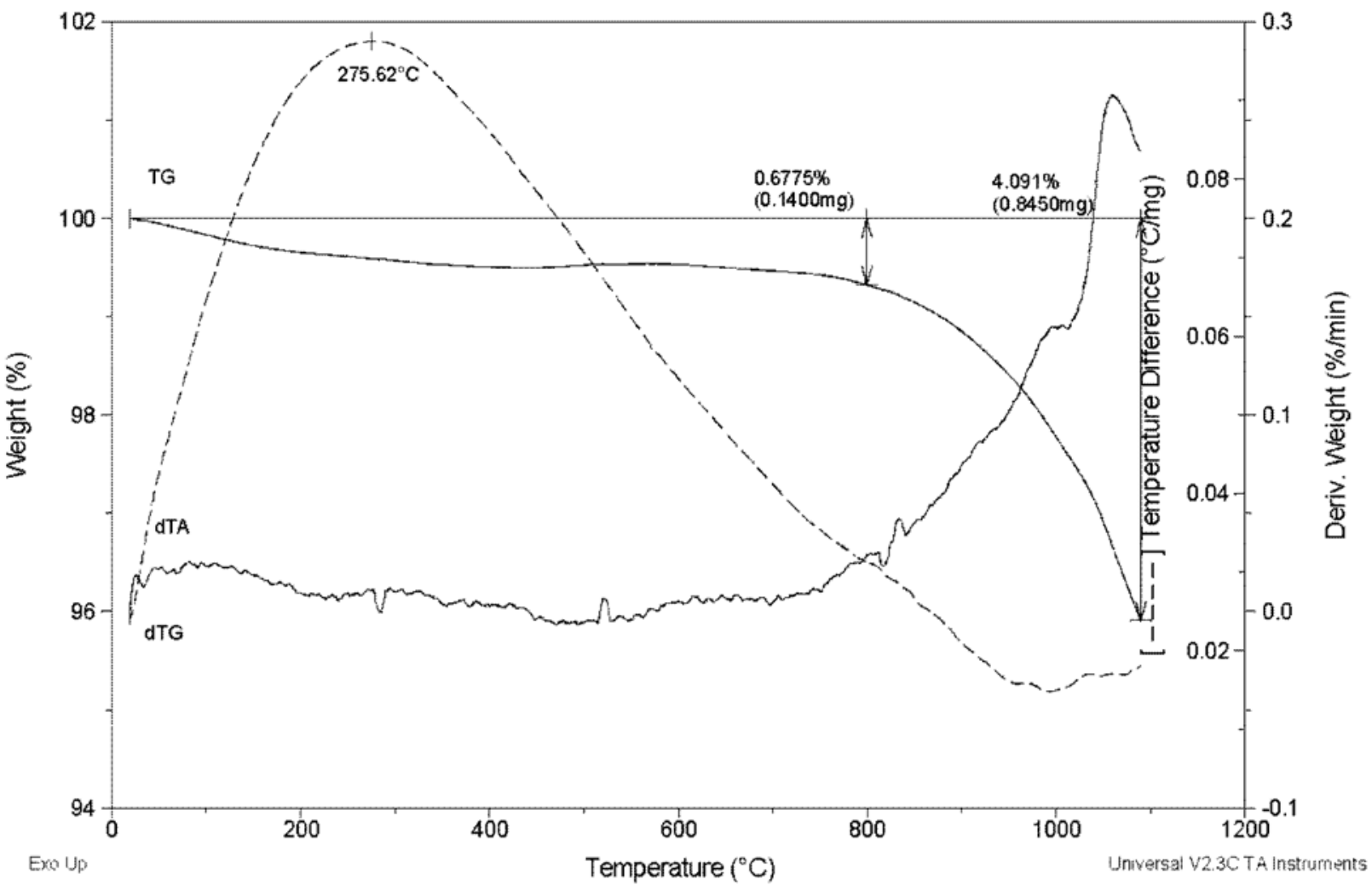

Sample

Size: $15.3030 \mathrm{mg}$

TGA-DTA

Comment: 10-1000 Powietrze

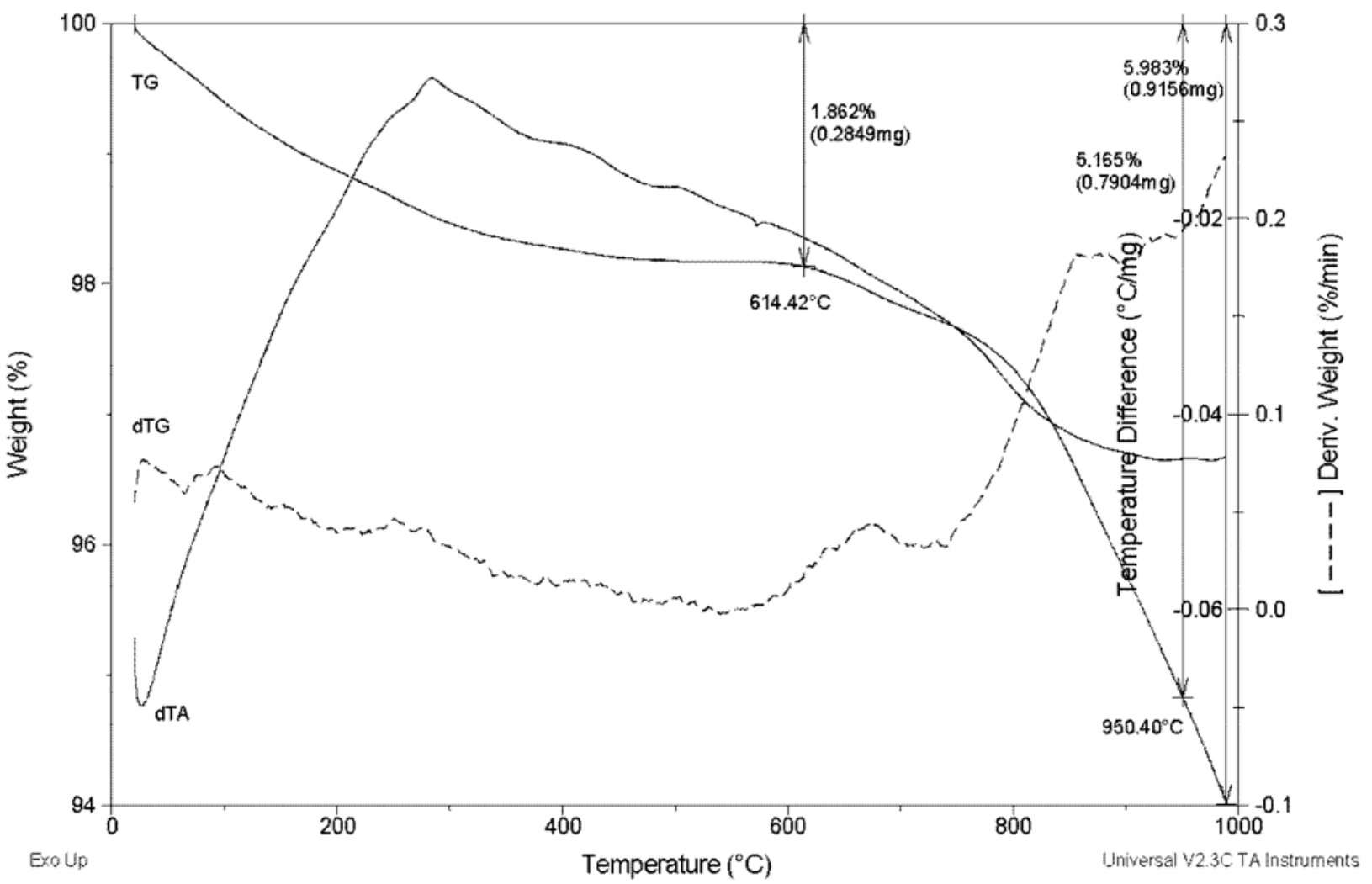

Figure 1. The Thermal Analysis results: a) industrial ash $A_{\text {ind }}$ b). laboratory ash $A_{\text {lab }}$ 

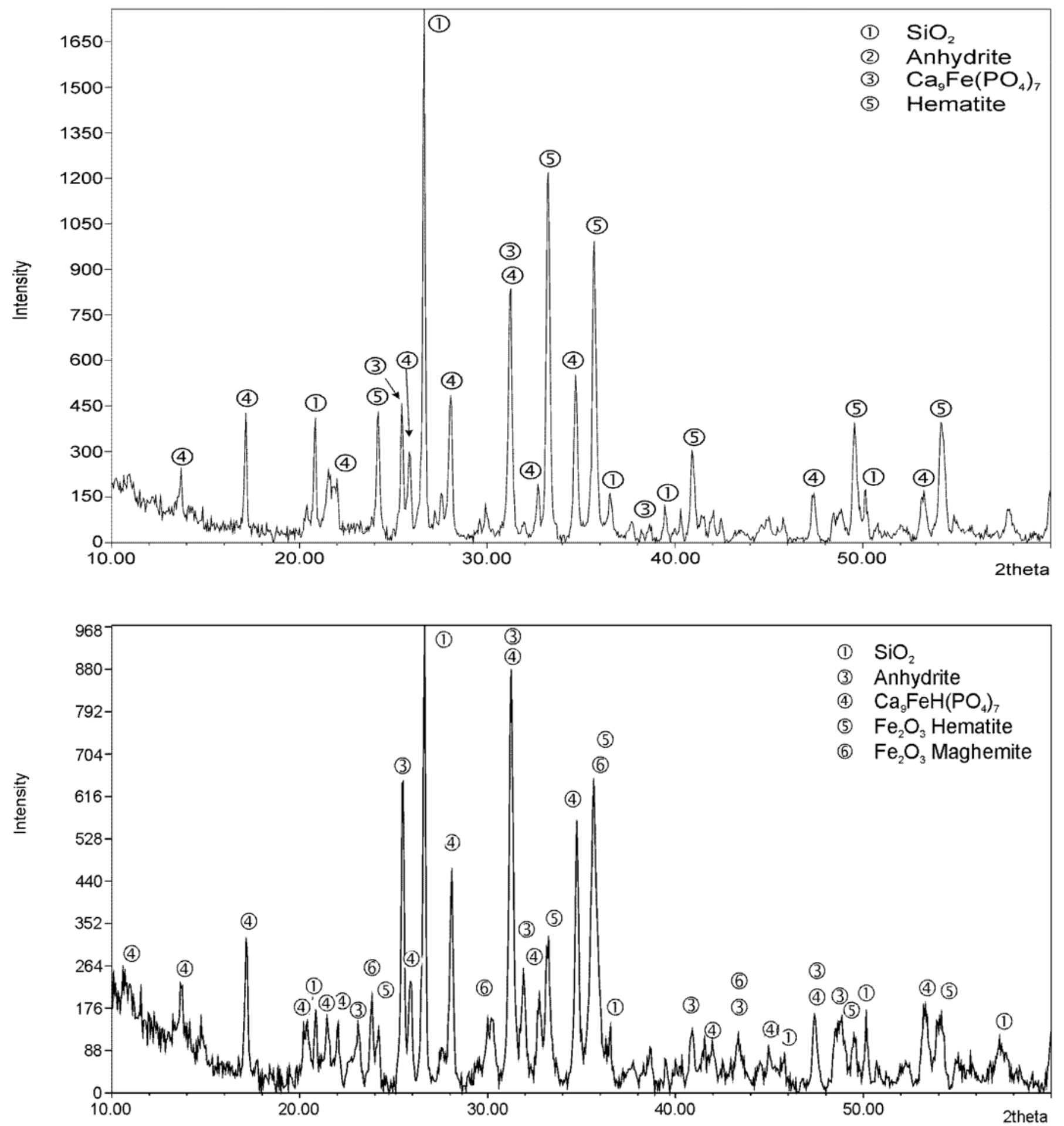

Figure 2. X-Ray Analysis : a) laboratory ash $A_{\text {lab }}$ b). industrial ash $A_{\text {ind }}$

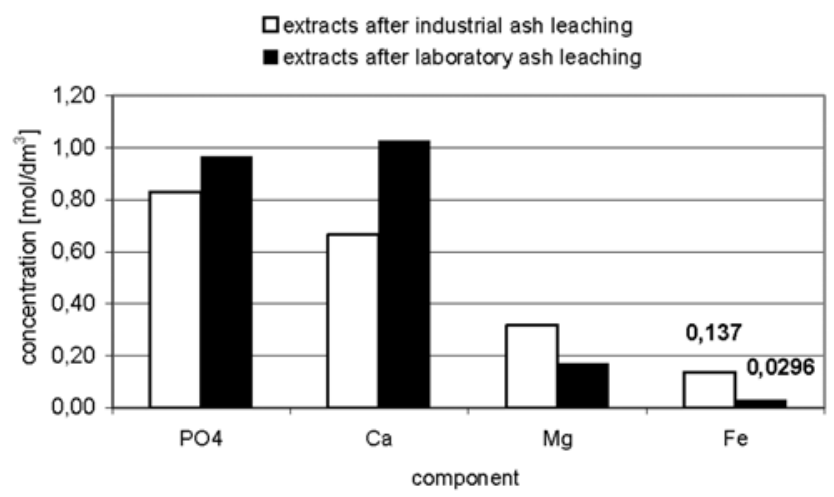

Figure 3. A comparison of $\mathrm{PO}_{4}^{3-}, \mathrm{Ca}^{2+}, \mathrm{Mg}^{2+}, \mathrm{Fe}^{2+}$ concentrations in the extracts after the laboratory $\left(A_{\text {lab }}\right)$ and the industrial $\left(A_{\text {ind }}\right)$ ash leaching with phosphoric acid

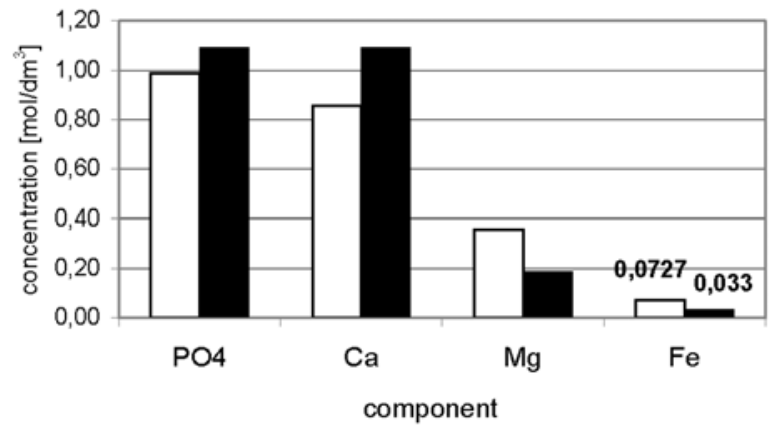

Figure 4. Comparison of $\mathrm{PO}_{4}^{3-}, \mathrm{Ca}^{2+}, \mathrm{Mg}^{2+}, \mathrm{Fe}^{2+}$ concentrations in extracts after laboratory $\left(A_{l a b}\right)$ and industrial $\left(A_{\text {ind }}\right)$ ash leaching with nitric acid 
The concentration of $\mathrm{Fe}^{2+}$ ions in the extracts after the leaching process strongly depends on the temperature and the way of thermal ash treatment. In the case of laboratory ash, when higher temperature of ash thermal processing was used as well as a longer time of retention in the furnace, the iron concentrations amounts were: $1.85 \mathrm{~g} / \mathrm{l}$ for nitric acid extraction and $1.67 \mathrm{~g} / 1$ for phosphoric acid extraction. These concentrations are considerably lower than in the extracts after the industrial ash extraction $4.07 \mathrm{~g} / \mathrm{l}$ and $7.67 \mathrm{~g} / \mathrm{l}$, respectively. It should be mentioned that iron quantities introduced into the extraction processes with the laboratory ash was almost three times lower than that of which was introduced with the industrial ash.

The $\mathrm{Fe}^{2+} / \mathrm{PO}_{4}{ }^{3-}$ mass ratio in the extracts, which indicates the selectivity of phosphorus compounds extraction towards iron, also decreases in the case of using a higher temperature of ash thermal processing in the case of laboratory ash. This parameter is two times lower for the laboratory ash extraction with nitric acid $(0.017 \mathrm{~g} / \mathrm{g})$ than that for the industrial ash $(0.036 \mathrm{~g} / \mathrm{g})$. In the case of the extraction with the use of phosphoric acid the $\mathrm{Fe}^{2+} / \mathrm{PO}_{4}{ }^{3-}$ mass ratio is even five times lower for the laboratory ash $(0.0181 \mathrm{~g} / \mathrm{g})$ than that of industrial ash $(0.091 \mathrm{~g} / \mathrm{g})$.

Consequently, more iron is stopped in the form of insoluble compounds in the solid residue after the laboratory ash extraction processes. In the case of the laboratory ash extraction with nitric acid the iron concentration in the solid residue amounts to $23.9 \%$ while with phosphoric acid $26.1 \%$ and in the case of the industrial ash $18.2 \%$ when nitric acid was used, while with phosphoric acid $14.6 \%$.

Taking into account further usage properties of the obtained extracts it is a very advantageous effect, because the presence of iron ions influence the phosphorus compounds availability, especially in fertilizers, unfavourably.

The X-Ray Analysis of the solid residue after extraction has shown that its main crystalline phases are $\mathrm{SiO}_{2}$, hematite and anhydrite (Figure 5 and 6).

The research results confirm that the selective extraction of phosphorus compounds from ash is possible because of the insoluble hematite phase appearance $\left(\mathrm{Fe}_{2} \mathrm{O}_{3}\right)$. Due to the higher incineration temperature of the sewage sludge, more iron compounds are transformed into the hematite phase and, as a consequence, the concentration of iron extracted simultaneously with phosphorus into solution, is much lower.

The $\mathrm{Zn}, \mathrm{Cu}, \mathrm{Ni}, \mathrm{Cr}, \mathrm{Cd}$, $\mathrm{Co}$ and $\mathrm{Pb}$ concentrations in extracts are shown in Table 4.

\section{CONCLUSION}

The conducted investigations confirm the influence of sewage sludge thermal processing on the usage properties of the obtained ash. In spite of the three times lower Fe

Table 4. The $\mathrm{Zn}, \mathrm{Cu}, \mathrm{Ni}, \mathrm{Cr}, \mathrm{Cd}, \mathrm{Co}$ and $\mathrm{Pb}$ concentrations in extracts after the laboratory $A_{\text {lab }}$ and industrial ash $A_{\text {ind }}$ extraction

\begin{tabular}{|c|c|c|c|c|c|c|c|c|}
\hline Experiment no & & $\mathrm{Zn}$ & $\mathrm{Cu}$ & $\mathrm{Ni}$ & $\mathrm{Cr}$ & $\mathrm{Cd}$ & Co & $\mathrm{Pb}$ \\
\hline \multirow{2}{*}{1} & $A_{l a b}$ & 0.82 & 0.113 & 0.0061 & 0.0056 & 0.0022 & 0.0023 & 0.019 \\
\hline & $A_{\text {ind }}$ & 2.05 & 0.119 & 0.0098 & 0.058 & 0.011 & 0.0026 & 0.0086 \\
\hline 2 & $A_{l a b}$ & 0.73 & 0.109 & 0.0052 & 0.074 & 0.0037 & 0.0039 & 0.026 \\
\hline
\end{tabular}

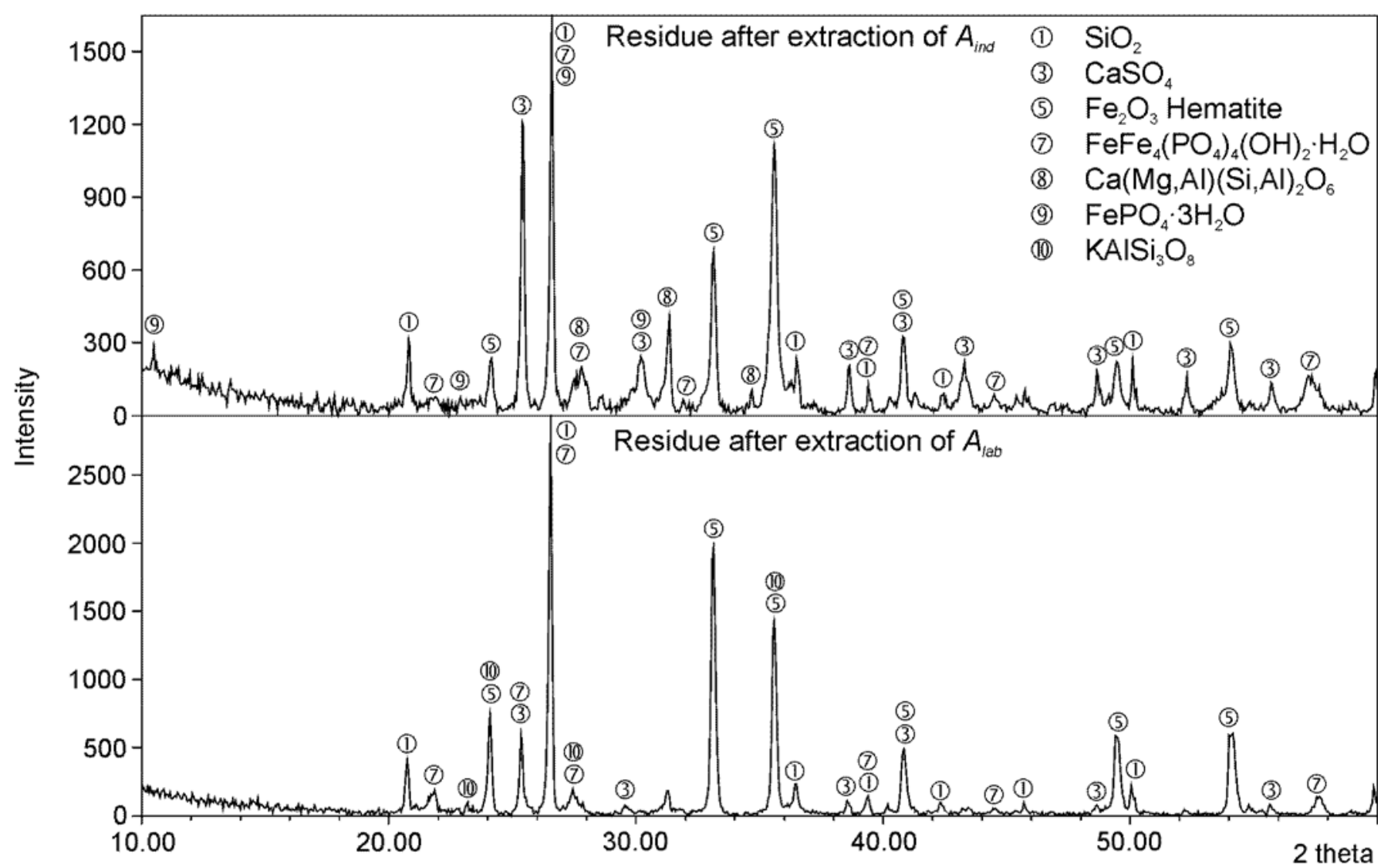

Figure 5. The X-Ray Analysis of the solid residues after an extraction of the industrial $A_{\text {ind }}$ and the laboratory $A_{\text {lab }}$ ash with phosphoric acid 


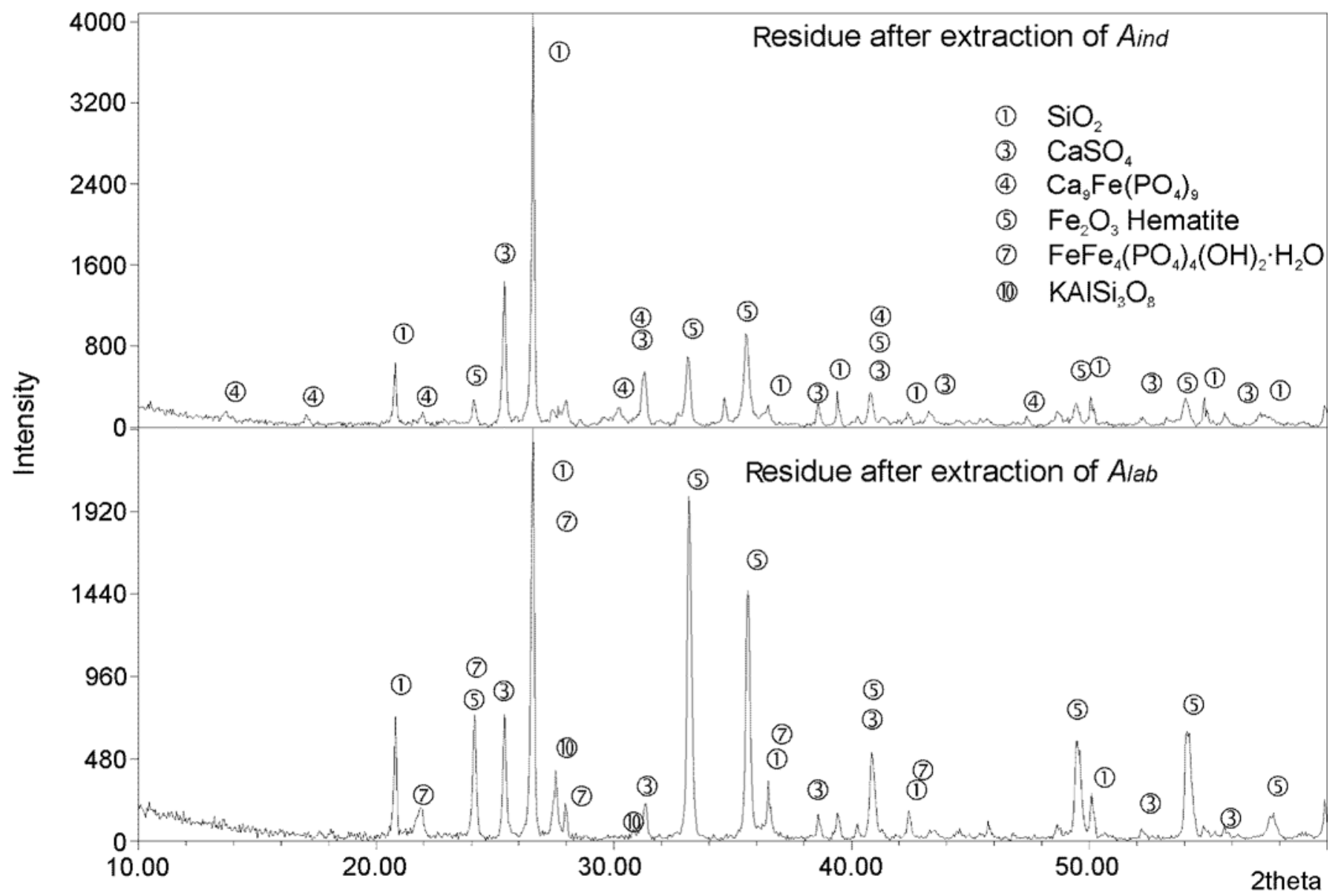

Figure 6. The X-Ray Analysis of the solid residues after an extraction of the industrial $A_{\text {ind }}$ and laboratory $A_{\text {lab }}$ ash with nitric acid

content in the industrial ash $A_{\text {ind }}$, its concentration in the extracts after phosphoric acid extraction was 4.7 times higher than in the extracts following the laboratory ash extraction. In the case of nitric acid extraction the $\mathrm{Fe}$ concentration was 2.2 times higher.

The solid residue after the industrial ash extraction contains more $\mathrm{PO}_{4}{ }^{3-}$ ions than after the laboratory ash extraction. The content of the $\mathrm{PO}_{4}{ }^{3-}$ ions amounts to $19 \%$ in the case of phosphoric acid extraction and $14 \%$ after nitric acid extraction.

The values of the extraction degrees are also lower in the case of the industrial ash extraction and reach $86.33 \%$ for nitric acid extraction and $81.07 \%$ for phosphoric acid.

The extraction productivity also insignificantly decreases.

The research results confirm that the thermal processing of sewage sludge is significant for further ash utilization and phosphorus compounds recovery. A higher temperature and a longer combustion process result in better ash parameters in the case of phosphorus compounds extraction with a limited transfer of ferrous ion into solution.

On the grounds of the conducted research, thermal utilization technologies should be selected on the basis of sewage sludge composition, control the combustion process such as to result in proper physicochemical characteristics of the ash produced with the view to further phosphorus compound recovery by means of selective extraction methods

\section{ACKNOWLEDGEMENT}

This study was supported in part by the research grant KBN 4 T09B 06824

\section{LITERATURE CITED}

(1) Bożym M., Wacławek W.: Problem zagospodarowania Osadów Ściekowych w Polsce, Krajach Unii Europejskiej i USA. Chemia Dydaktyka Ekologia Metrologia (Polish). 2000, 5, 105.

(2) Bień J., Kempa E.: Gospodarka osadami z oczyszczalni ścieków, inżynieria środowiska stan obecny i perspektywy rozwoju. Monografie Komitetu Ochrony Środowiska PAN (Polish). 2002, 10, 323.

(3) Data of Główny Urząd statystyczny (Polish), 2002. / unpublished/

(4) Steen I.: Phosphorus availability in the 21st century: Management of a non-renewable resources, Phosphorus Potassium. 1998, 217, 25.

(5) Driver J., Lijmbach D., Steen I.: Why recover phosphorus for recycling, and how?. Environ. Technol. 1999, 20, 651.

(6) EU considers tighter sludge spreading rules, CEEP Scope Newsletter. 2000, 37, 2.

(7) Dulley B.: Recycling phosphorus by recovery from sewage. Second International Conference on the recovery of phosphorus from sewage and animal wastes, $12-13$ march 2001. http://www.nhm.ac.uk/mineralogy/phos/Duley.doc

(8) Andersen A.: „Disposal and recycling routes for sewage sludge" report for the UE Commission-DG-Environment-B/2,SEDES. http://europa.eu.int/comm/environment/ waste/sludge/sludge_disposal.htm

(9) Takahashi M., Kato S., Shima H., Sarai E., Ichioka T., Hatykawa S., Miyajiri H.: Technology for recovering phos- 
phorus from incinerated wastewater treatment sludge. Chemosphere. 2001, 44, 23.

(10) Jozuka T.: P-recovery from sewage sludge incineration ash. CEEP Scope Newsletter. 2001, 43, 7.

(11) Suzuki Y.: P-recovery from sewage-sludge incineration ash. CEEP Scope Newsletter. 2003, 52, 4

(12) Nakahara: et al. Method for recovering phosphorus from organic sludge. US Patent 6,022,514. 2000.

(13) Wzorek Z., Jodko M., Gorazda K., Rzepecki T.: Extraction of phosphorus compounds from ashes from thermal processing of sewage sludge. J. Loss. Prevent. Proc. 2006, 19, 39.

(14) Gorazda K., Kowalski Z., Wzorek Z., Jodko M., Rzepecki T., Kulczycka J., Przewrocki P.: Possibilities of phosphorus recovering from municipal sewage sludge. Pol. J. Appl. Chem. 2003, 2, 51.

(15) Kowalski Z., Wzorek Z., Jodko M., Gorazda K., Przewrocki P., Kulczycka J.: Thermal utylization of sewage sludge in Poland. Miner. Energ. 2003, 2, 34.

(16) Gorazda K., Kowalski Z., Wzorek Z., Jodko M.: Phosphorus compound extraction from ash after the sewage sludge combustion. Pol. J. Chem. Technol. 2005, 7, 24.

(17) Rzechuła J., Hupka J.: Charakterystyka i możliwości zagospodarowania popiołów i żużli ze spalania odpadów. Paliwa z Odpadów (Polish). 2003, 5, 243. 